\section{Penicillin Committee}

Sir Andrew Duncan, Minister of Supply, has announced that Sir Henry Dale, president of the Royal Society, has been appointed chairman of the Penicillin Committee. The Committee is constituted as follows: Mr. Arthur Mortimer, deputy director of medical supplies, Ministry of Supply (vice-chairman) ; Dr. V. D. Allison, Ministry of Health ; Lieut.Colonel H. J. Bensted, Army Medical Department, War Office; Prof. R. V. Christie, Medical Research Counctl, director of the Medical Professorial Unit at St. Bartholomew's Hospital, London; Dr. A. N. Drury, Medical Research Council, director of the Lister Institute; Prof. A. Fleming, professor of bacteriology in the University of London (St. Mary's Hospital Medical School); Prof. H. W. Florey, professor of pathology in the University of Oxford; Dr. C. R. Harington, secretary of the Medical Research Council ; Prof. I. M. Heilbron, professor of organic chemistry in the Imperial College of Science and Technology and scientific adviser to the Minister of Production; Prof. R. P. Linstead, deputy director of scientific research, Ministry of Supply, professor of organic chemistry, Harvard University ; Prof. H. Raistrick, professor of biochemistry in the University of London; Sir Robert Robinson, Waynflete professor of chemistry in the University of Oxford ; Sir Russell Wilkinson, military medical adviser, Ministry of Supply ; and representatives of firms engaged in the production of penicillin.

\section{Intelligence and Season of Conception}

IT is beyond reasonable doubt, according to Dr. J. Fraser Roberts (Brit. Med. J., March 4, 1944, p. 320), that children conceived in winter are, on the average, somewhat more intelligent than those conceived in the summer; but this fact has been almost universally misinterpreted. Practically every hypothesis brought forward to explain it has de. pended on the assumption that it is the season of conception that influences the intelligence of the child. Some have even urged the benefits of planned winter conception (for example, Mills, C. A., Human Biology, 13, 378; 1941). Dr. Fraser Roberts has tackled the problem by comparing winter and summer children born to the same parents, arguing that, if the season of conception influences the intelligence of the child, the usual difference will be found in such groups; if, however, the real explanation of the observed difference is the fact that the intelligence of the parents influences the season of conception, the two groups will show no difference. A second line of inquiry was the determination of the number of sibs of comparable groups of winter and summer children. Admitting that the evidence that he has gained is not based on very large numbers, Dr. Fraser Roberts concludes that the rather greater intelligence of the child conceived in winter is not due to seasonal influences on the mother or on the developing child; but to the tendency for the more intelligent parents to conceive children rather more often in the winter, while the less intelligent people tend to conceive children rather more often in the summer.

\section{Sunflowers as an Oil Seed Crop}

Is the February issue of Agriculture there is an account of the progress made during the last four years on the development under English conditions of the sunflower as an oil seed crop, which was also referred to by Mr. E. F. Hurt in a lecture to the
Royal Horticultural Society (NATURE, February 26, p. 248). This work, started in 1940 at the Imperial College of Science and Technology by Mr. G. E. Blackman, has since been continued by him and a research team under grants from the Ministry of Agriculture and the Agricultural Research Council. To date it has been found that only semi-dwarf varieties, capable of ripening seed in August or early September, are suitable to Great Britain, for the giant varieties, which mature in the autumn, are very prone to attack from Botrytis. Besides the selection of three varieties-'Pole Star', 'Southern Cross' and 'Mars' - the course of the investigations has demonstrated the primary importance of spacing in controlling maximal yield and the relative small part played by soil type or manuring. By close spacing, yields much in excess of the average in other sunflower producing countries have been obtained, while the seeds are not inferior in the quantity and quality of the oil and protein. In addition, methods of harvesting and threshing suitable for English conditions have been devised. In 1943 , the crop was first grown on a field scale on some twenty farms and this year the developmental work is to be expanded. The outlook for sunflowers as a new crop in England appears of distinct promise.

\section{Vacation Work Scheme of the Imperial College}

THE Imperial College Union in its ninth annual report of its vacation work scheme shows an interesting record of development for the past year. Under this scheme, students of the Imperial College of Science and Technology are placed, during their vacations, in works and laboratories of industrial firms and of research institutions. During 1943, nearly 500 students registered for this purpose as compared with 180 in 1941 , and 226 firms co-operated in this enterprise as against 324 , so rapid has been the growth in popularity of the scheme. One of the most significant and welcome features is the extent to which firms have willingly co-operated in securing to the students entrusted to their care, the best possible and the most varied training and experience during their time at these institutions. In many cases a survey of the organization and administration is provided by lectures and tours conducted by members of the staff, in addition to the opportunity to take part in the productive processes in factory, workshop or laboratory. In this way the vacation work scheme at the Imperial College would appear to add to the theoretical studies of the students, whatever their branch of science or engineering, a valuable insight into the structure of industry, and enables them to see at first hand how wealth in the true sense is created from the organized skill and experience of all grades of workers, and how the various branches of science contribute in practice to this end.

In December 1943, the vacation work committee convened a highly successful conference of representatives from a number of the co-operating firms, at which a searching analysis was made by many speakers of various aspects of this scheme. From this it was evident how conscious were these institutions and firms of the part they have to play, jointly with the universities and technical colleges, in the creation of a highly trained body of scientific and technical workers. The scheme is under the chairmanship of Prof. H. Levy, who represents the governing body of the Imperial College ; the secretary of the vacation work committee is Mr. J. Newby. 